\title{
Alveolar's International Human Resources Faux Pas: Their History And One Manager's Influence
}

Nivia A. Navia, Nova Southeastern University

Bahaudin G. Mujtaba, Nova Southeastern University

\begin{abstract}
The purpose of this case is to instill in the reader the importance of human resource management policies and practices and how they contribute to an international company's competitiveness. International Human Resources Management (IHRM) and sound HR practices should be present at all levels within the context of strategic business objectives, culture, and resources management constraints. This case will showcase Alveolar International, Inc., an international corporation that specializes in the manufacturing and sales of dental implants. It will include an overview and history, an analysis of their management constraints, some examples of non-compliance of HR practices within the firm and its effect on employee morale, and lastly, the actions that should have been taken place from an IHRM perspective. An explanation will be provided as to how these very same blunders could have potentially contributed to the sale of the company and, furthermore, the takeover of Alveolar in a recent merger. The analysis is provided to the reader from the perspective of an employee of the corporation as well as a researcher. It should be noted that for the protection of employers and employees, the identities and names of those involved have been changed.
\end{abstract}

\section{INTRODUCTION AND ALVEOLAR'S OVERVIEW}

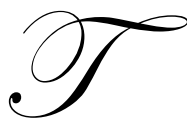

he management practices of every corporation seem to be greatly influenced by the daily habits and behaviors of their managers, especially senior executives and founders. These management practices and daily habits or behaviors tend to impact motivation, employee morale, employee retention, and the overall success of the organization. Therefore business schools, educators and trainers should focus on the realities of the present work environment in order to better prepare tomorrow's workforce for the challenges they are likely to face. Richard Schmalensee (2006, p. 118) said, "To our critics, including many successful managers, business schools have become little more than exercises in ticket punching for would-be consultants, taught by faculty who are more interested in impressing their academic colleagues than in confronting real-world business problems." Schmalensee recommends that the relationship between business educators and business professionals should extend beyond formal classes and curriculums. Furthermore, the research conducted by business schools should be driven by real-world management challenges, successes, and faux pas. This case about the fictional company, Alveolar, is based on a real world organization and its employees in hopes of extending the bricks in building a bridge to eventually close the gap between academia and what managers actually practice in their day-today operations.

Headquartered in Deerfield Beach, FL, with operations worldwide, Alveolar's history began thirty-six years ago with the manufacturing of the first blade implant by Dr. Leonard Linkow. Shortly thereafter the company subcontracted several early root form implants before introducing its own product line known as the Minimatic Implants in 1990. The following decade brought upon the acquisition of Ortho-generation Corporation for its revolutionary advances in cell biology and biomaterials. Ortho-regeneration now serves as Alveolar's research and development division and is staffed by industry renowned biomaterial engineers, M.D.'s and Ph.D's such as NYU's own Dr. Jack Ricardo and Dr. Harry Alexis. Ortho-regeneration is part of the brains and heart of the company for its 
purpose is to focus on furthering the understanding of cellular responses so that the company is able to aggressively improve and simplify clinical results and implant therapy (NAI, 1 n.d.).

\section{Alveolar's Vision And Innovations}

"Alveolar will vigorously expand and apply our knowledge of cell biology and biomaterials to create innovative products providing patients with aesthetic results that last a lifetime and clinicians with a simple, user friendly system. Alveolar will lead the dental implant industry in the areas of scientific discovery and practical innovation through our drive to improve patient outcomes and simplify implant therapy (NAI, 1 n.d.)." The following are some of their innovations:

- $\quad$ "1991 and throughout the next seven years Alveolar introduced the $91^{\circ}$ Hexed Interface for Abutments providing a "friction" connection, patented Reverse Buttress Implant Thread which improved load distribution by up to $34 \%$ over traditional "V" threads, created the patented Dual Journal Abutment Screw, a design that prevents screw loosening by shielding the threads from lateral forces.

- 1998 Introduced Silhouette Implant. The first Straight/Tapered Hybrid combines ease of placement with high primary stability and wide range of indications.

- $\quad 2000$ Lok-Screw ${ }^{\circledR}$ Secondary Abutment Screw. Eliminates abutment screw loosening even in the most demanding cases.

- 2004 Introduced Bio-Cera Ceramic Abutments. Unique Zirconia alloy increases strength allowing for $15^{\circ}$ and $25^{\circ}$ angled ceramic abutments.

- $\quad 2006$ Launched Laser-Lok® Bioaffinity Collar. The first implant to achieve Endosseous Incorporation (both soft and hard tissue integration)" (NAI, 1 n.d.)".

\section{Management Constraints}

Although Alveolar's history of innovations captivates an audience as trendsetters in the dental implant industry, there is much to be said about their management styles and practices. The matrix structure that the company adheres to is the top down approach wherein management decisions are made at the top level mainly with executives and subordinate employees are not encouraged to express concerns or opinions. This management style has lead managers to depend and rely on their ability to control employees which has ultimately lead some employees to feel that they are not listened too, and that their voices do not count. It is known that when employees are treated poorly morale plummets and a general lack of support will result (Robertson, 2003).

Morale at Alveolar has been tremendously bleak since the company made a formal announcement that it was not being sold despite rumors that had been circulating to the contrary. With this announcement came a reassurance from upper management that all employees would keep their jobs. The problem with these announcements is that they were not true as the company was sold shortly after the announcements were made and a majority of the employees were informed that their positions had been eliminated. This was the apex for an organization with a long history of ineptness in human resource management that will be explored further in this case.

Let us begin with some of the management constraints that Aivin has personally encountered throughout the last year and 10 months of employment with Alveolar. The CFO/EVP of the company before sudden retirement after its sale was Ian who has worked for Alveolar for over fifteen years. Ian set the foundation for management practices at Alveolar and was a knowledgeable CFO in various aspects of the company however he also had a particular air about him. In particular, this man had exemplified himself as one with little patience and had a knack for yelling at employees so loud that others could hear through a closed-door office. Most employees of the company dreaded having to work and deal with Ian whether it is on a daily, weekly, or even monthly basis.

Due to the fact that he was the CFO of Alveolar, he had always worked closely with the Accounting Department. There was a direct correlation between him and high employee turnover rate which was and is currently still the highest throughout the firm. During the period of 22 months of Aivin's employment with the company there 
have been over 14 new hires for the accounting department that only staffs four people on a regular basis. Every single one of the ex-employees of these departments have expressly voiced to Aivin that Ian's verbal abuse was one of the major reasons as to why they chose to seek employment elsewhere. When Aivin questioned them what the second reason was, they all replied with a similar scenario which was unhappiness because of the way the company was run and they all felt taken advantage of and undervalued. A contributing factor to the high turnover rate at Alveolar could be Ian's approach in management style. Perhaps a more helpful approach would be to have more patience and control of one's anger.

A personal example that Aivin endured with Ian was one of the many days where she was asked to provide phone coverage at the reception desk in place of the Executive Assistant that was not present. Aivin was just getting off a phone call when a fellow employee was talking about the system (AS 400) being backed up again so that she could resume her duties efficiently when another call went through. Ian overheard the conversation not realizing Aivin was on the phone and proceeded to yell at her for no apparent reason after not catching the full scope of the previous conversation and put his two cents in which were irrelevant after only catching half of the story. Luckily, the call that Aivin received was from her direct boss, VP of International Sales, Peter.

Peter had heard yelling in the background and right away knew it was Ian and finished up the conversation quickly. After the call ended Aivin specifically said in a low tone, "Ian you can't do that I was on the phone and the person on the other end could hear you yelling at me, it looks extremely unprofessional," and until this day Aivin will never forget Ian's reply as he wagged and pointed his finger about 5 inches from her face, "Listen to me, don't you ever talk to me like that again or I will throw you out this door myself (his other hand motioning to the front office doors), I don't care who you report to, you got that!"

Naturally Aivin was enraged and asked a co-worker to fill in for her while she phoned her boss to ask for a meeting as soon as he arrived to the office. Aivin later explained the occurrence to him and expressed that she was extremely outraged as to how the situation was handled and that she did not have to endure such maltreatment in the workplace and that she would not tolerate the hostility. Aivin said to Peter "that Ian posed a physical threat to me by saying he was going to throw me out the door himself and that I had the right mind to hire a lawyer, call the Better Business Bureau, The Department of Labor and Healthcare Incorporated (the company whom eventually bought Alveolar) as well as Horizons Dental the later successor of the company merger and let them all know what kind of CFO they are taking on by doing business with us."

Later that day Aivin was brought into a meeting with both Peter and the Alveolar's Ex-President, Barry, where he apologized for Ian's behavior and assured her that she handled the situation with class and poise. Unfortunately this apology really did not make a difference to Aivin as the humiliation of the occurrence had already set in. The reader at this time may question why Aivin didn't walk out after such hostile and unprofessional treatment. The reason was because Aivin had planned events for the remainder of the week for the distributor from Argentina as well as a group of Argentinean doctors that were joining them for a company visit the very next day. Her cultural values would not permit her to abandon her boss Peter nor would she disappoint and possibly hinder her distributor relationship and ultimately cause him to look bad in front of his invitees. There was too much at stake if she were to act in the same impulsive manner as Ian.

This story exemplifies a perfect example of controlling one's emotions in the workplace as well as professional demeanor. Also, this is an example of direct violation of the Alveolar employee handbook section 522, page 56, referring to Workplace Violence Prevention, where it specifically states, "This policy explains guidelines for dealing with intimidation, harassment, violent acts or threats of violence that might occur during business hours or on our premises at anytime. You are expected to treat co-workers, including supervisors and temporary employees, with courtesy and respect at all times (NAI, 2, 2006)." Furthermore, the handbook states that this should be reported to a supervisor or another member of management which was done on Aivin's behalf and the noncompliance on the part of Alveolar was that the person committing the violent act and or threat was to be subject to disciplinary action up to and including termination, however, none was taken. 
The next question the reader may pose is why this incident was only reported to her direct boss as opposed to the HR department; naturally a complaint could have been filed in writing, right? Measures such as these could have been taken at Alveolar; however Aivin chose not to for two reasons, one being conflict of interest since Darlene, the HR manager directly reported to Ian and dealing with Darlene is one of her least favorite things to do. Darlene is unfortunately despised by many employees of Alveolar and is commonly referred to as "Dirty D" or "Cruella." Perhaps the reader may be wondering why she is referred to like this? What is about to unfold can be viewed as extremely disturbing especially for someone in a human resource position.

\section{Non- Compliance Of HR Practices}

Human Resource Managers should be primarily concerned for the well-being of the firm's employees, human resource planning, staffing, performance management, training and development, industrial relations, and compensation and benefits (Dowling \& Welch, 2005). Unfortunately for Alveolar, Darlene is the HR professional and in Aivin's opinion doesn't seem to take her job seriously especially when she shares her personal life choices with certain employees. It is highly unlikely that professionalism for any management position include sharing stories of fetish club attendance, smoking marijuana, and sharing stories of her sexual relations with various people met online. This behavior is unacceptable for any employee to share, let alone a manager and especially for an HR professional that is expected to exude a professional demeanor.

One of the most common blunders among some HR professionals is failing to think like a business professional. "HR exists for one reason and one reason alone: to help the company perform," says Scott Cawood, founder of the New York-based consulting firm ModernThink. "In order to help a business perform, the HR person must understand how it makes money, where it spends money and, most importantly, how it can make more money." From an HR standpoint sharing personal choices with employees in raw conversations such as the ones previously mentioned proves that Darlene has lost perspective and has forgotten her role, power and purpose (Cornell, 2006).

This next episode is a further illustration of Darlene losing perspective. January of 2006 was the first time in Alveolar's history where an employee handbook was distributed and according to section 702, page 60 in the handbook, alcohol and drug use is against company policy and states that "employees may be asked to provide substance samples such as urine and or blood and these samples will be used to check for illegal or illicit use of drugs and alcohol (NAI, 2 2006)."

An employee by the name of Rhonda, who coincidently was hired by Darlene and is also her roommate, recently had a motorcycle accident for which she was hospitalized for broken ribs. The cause of her accident was announced by Darlene to several employees in confidence, including Aivin and two other co-workers. The cause of the accident, it turns out, was that Rhonda was under the influence of marijuana while operating her motorcycle. Knowing this, what comes to mind is yet another example of policies and procedures not being applied to everyone throughout the firm equally. It is appalling to know that the HR manager herself has violated Section 104, page 4 Code of ethics for officers and managers where it states "Honest and ethical conduct, including ethical handling of actual or apparent conflicts of interest between personal and professional relationships (NAI, 2 2006)." Having known information that directly violates company policy Darlene should have had Rhonda tested for drug abuse; however, Darlene blatantly ignored this incident and by doing so, condoned the behavior. Perhaps if Darlene had taken the proper measures as an HR professional instead of a "friend/roommate" she could have helped Ronda move past this point in her life.

Failure to establish clear performance objectives and employment evaluations within a firm can be dire to its turnover rate. In yet another display of HR incompetence, Alveolar has not provided its employees current job descriptions delineating major responsibilities, limits of authority, performance expectations, and evaluation methods (Massad, n.d.). Without clear, written expectations an employee may find it difficult to establish and perform his or her duties. There is a possibility that this has also lead to high employee turnover. An example of high turnover within Alveolar but outside of the accounting department is the position of Executive Assistant to the 
President. Since Aivin has been employed, there have been seven different Executive Assistants. This shows that turnover is not a department specific issue but rather a company-wide dilemma.

The high turnover rate for this particular position could have been attributed to the Ex-President's attitude toward women, especially those he worked closely with. One example of how a situation was handled improperly was when the Executive Assistant, Shana, had worked directly under Barry. Barry had what some might say a warm personality and sometimes so warm that oftentimes made some females feel a little uneasy. In particular, Shana had mentioned to Aivin that she felt uncomfortable around him especially when he came over to her when he wanted to provide direction to her for certain projects. She specifically told her that he would constantly rub her back while he was talking to her as she sat at her desk. The only advice Aivin ever offered her was to directly confront him one day when he did that again and let him know that it made her feel uncomfortable; however, Shana's personality is not exactly the type to confront situations as she is very quiet and unassuming.

Time went by and she finally reached the point where she had had enough and decided to address the ongoing issue with HR as it falls in direct violation of Section 522, page 56 of the Alveolar employee handbook, where it states, "We do not permit any act of harassment including harassment that is based on an individual's sex, race, age, or any characteristic protected by federal, state or local law." Darlene comforted her and let Shana know that she would fully support her if she decided to take this any further with the next step being a written statement provided by both parties. Darlene also confided in Shana telling her that this was not the first complaint taken to her by female employees throughout the years and that Barry needed to learn his lesson and face the consequences. Evidently, Darlene had a knack for confiding in people because after the 2005 Holiday party some employees went out after work and it was then that Darlene confided in Aivin a similar story about Barry which took place a few years before Shana was even hired. Once again, Darlene has directly violated the company's code of ethics for lack of "respect for confidential information acquired in the course of ones work except when otherwise legally obligated to disclose such confidential information (NAI, 2 2006)." For the record, Shana was not yet an employee of Alveolar at the time of the social gathering when Darlene told Aivin this. When it came time for Barry's written statement, Darlene called a meeting between the three of them in Barry's office and completely downplayed what had been discussed in the HR office between Shana and herself. Darlene had completely "flipped the script" so to speak. Nonetheless, Barry was appalled by the supposed accusations of distasteful behavior on his part as owner and President of the company. During the ensuing weeks Shana had been coming to work in a somber state and often talked about looking for a new job because of the everyday awkwardness she had to endure. Luckily for her, the marketing department was hiring for Events Coordinator and she applied and got the job. Shana's story took a turn for the worse when the company merger and acquisition took place.

Poor documentation of clear expectations and progressive discipline are essential for an employee to recognize and learn their role within the firm. If the HR manager had documented job descriptions and duties there would have been less interaction between Barry and Shana. In any case, this does not excuse Barry's behavior toward women nor does it excuse the grossly improper HR practices exhibited by Darlene in a very serious situation. If Shana had a different personality, Barry's actions could have led to a sexual harassment lawsuit.

\section{International Human Resource Practices}

The HR Manager, Darlene, is very limited in her role on an international level, as the firm has allowed its subsidiaries the power to do most of its hiring and distributors are also in charge of their own organizations. Supervision and evaluation of the subsidiaries and distributors is mainly conducted by the VP of International Sales, Peter. However there have been some exceptions when it comes to hiring for the Australian and Mexican Subsidiaries in terms of the accounting department. Managers from headquarters travel to these countries to fill these positions to ensure that the books are treated the same and follow U.S. GAAP practices. As the corporate HR manager, Darlene would primarily be concerned with expatriate management, however, since Peter falls under commuter/virtual based assignments, most of the research when traveling abroad is done by Aivin as this fulfills one of her duties as the international sales coordinator. 
Commuter assignments are "special arrangements where the person concerned commutes from the home country on a weekly or biweekly basis to the place of work in another country" similar to virtual assignments "where the employee does not relocate to host location but manages, from home base, international responsibilities for a part of the organization in another country (Dowling \& Welch, 2005)." Peter falls in between both of these as he has his home in Florida yet sometimes is absent from the home country for a month or longer at a time while traveling abroad from one country to the next for courses, tradeshows, lectures, etc.

Since Alveolar is not as what some refer to as a firm with a global presence it does not have to endure the complexities such as international taxation, international relocation, orientation, host government relations and administrative services for "traditional expatriates." Traditional expatriates are those that are moved across national boundaries into various roles within the international firms' foreign operations (Dowling \& Welch, 2005)." Hence, for Alveolar, international human resources are practiced at a minimum. One exception being the hiring for the international department and marketing department; when these decisions were made, HR was responsible to hire someone that is bilingual both verbally as well as written so that the company would not have to incur language translation costs for marketing collateral, and correspondence with distributors and subsidiaries. The distribution of marketing collateral seems to incorporate somewhat of an ethnocentric approach since this is predominantly done in English. The only marketing collateral ever made for another culture took place when the company made posters for the Latin American Market and this was only feasible because the marketing coordinator was bilingual. Many distributors and subsidiaries of a variety of cultures have voiced their complaints in regards to lack of support in this area.

Perhaps Alveolar should adopt a regiocentric management approach which could possibly offer the greatest potential for success for the firm instead of picking and choosing when something is suitable. Furthermore, as mentioned earlier, when subsidiaries of Alveolar are hiring for accounting positions, headquarters is typically involved in the interview and training and development processes, however it is important to note that different countries like taking different paths and human resources management practices are constantly changing to serve the needs of the new structure where they are adjusted accordingly (Dowling \& Welch, 2005).

International assignments are not limited to Peter but they are also given to the doctors of NYU, UMDNJ, and Ohio State faculty as speakers for multiple tradeshow events as well as for courses requested by distributors and subsidiaries. In preparation for these assignments the doctors direct questions to both Aivin as well as Peter. Some questions are those such as risk exposure, external influences, tourist sites to visit, local food, cultural habits, documents required for travel, and proper exchanges of business jargon. Mostly, the doctors want to know what not to do. Questions such as these are Aivin's responsibility and many times if she does not know something she will simply ask the distributor or subsidiary of the country requesting a speaker. Since there is an established relationship present there is a level of comfort where they would not view questions such as these as rude but instead are delighted and flattered to help. This is proof that when practicing in any international relations it is pertinent to have a good understanding of cultural values and norms.

\section{Acquisition And Merger Of Alveolar}

In October of 2006, rumors abounded at Alveolar regarding the possible sale of the company. As is the case in office environments throughout the world, rumors spread quickly. What made this situation particularly unique was the apparent source of the rumors. Legal documents regarding the proposed sale and merger were sent to the main fax machine in the office where they were visible to any employee who might happen to be close to the fax machine. This was another example of poor management. After upper-Management had found out about this, Barry, the President at the time, decided to hold a mandatory company meeting stating that there is absolutely no sale of the company and that the company is only seeking extra capital to fund production capacity.

Approximately one week followed where another mandatory meeting was called and it was announced that there was a sudden turn of events and that Alveolar was in the process of being acquired by Healthcare Incorporated, a research-based private equity firm with exclusive focus on the orthopedic and dental industries with over $\$ 500$ million in revenue currently under management. During this announcement Barry stressed that no one would be 
losing their jobs. It is important to note that Healthcare Incorporated also recently acquired Horizons Dental Implant Systems with the intent of merging Alveolar International Inc. to build a world-class dental implant company. The reasoning is simple - each company's weakness is the other's strength. With $70 \%$ of revenue earned in international sales and only $30 \%$ domestically, Alveolar seemed to be the perfect fit with counterpart Horizons Dental Implant System as the majority of their revenue comes through domestic sales.

Barry's failed attempt to save face with the employees was a critical mistake when it came to employee trust and loyalty for the company. Many employees felt that Barry and the company as a whole had lied to them to look good and gain employee confidence and trust while the outcome was the exact opposite. The factor that damaged employee morale the most was that management had promised employees their jobs were safe and then in December of 2006 the first employee to be terminated was none other than Shana, just in time for the Holidays. She was let go and was given two weeks severance. Shortly after others were let go, one could say that her being let go first seemed a bit peculiar given the events of prior months. Within the course of a month, every employee was called into a meeting with Barry as well as a managing director for Healthcare Incorporated, to discuss their future with Alveolar.

Contrary to how employees of Alveolar found out about the recent acquisition and merger of the company, reported advice from Associates Inc. is that the hard work should be done up front. They specify to "be transparent and forthright in your own actions and expect the same from your counterparts in the other association. If you encounter a tough decision--such as post merger roles for senior staff--work it out prior to the legal merging of the two entities. You pay now or you pay later; any lingering issues will be a distraction to integrating and operating as one team. If you can't resolve a difficult issue before the merger, what makes you think you can resolve it afterward (Marks, 2005)?" One can note that being upfront and forthright hardly seems to be what Barry chose when he scheduled the first and second meeting. The outcome resulted in unhappy, disappointed employees followed by poor morale and ultimately less productivity throughout the firm. An example of effectively aiding a merger is clear communication. "Effective communication is two way, so you need to ask people what is going well and what is not. Actions such as employee-attitude surveys are cost-effective ways to monitor your people during a merger (Marks, 2005)."

An example of poor communication can be demonstrated on what happened to Aivin's fellow employee who works in the customer service department. This particular employee had the option to move to the state where the surviving entity will have its headquarters. She accepted the offer and the day she was ready to leave she received a call and was asked to unpack and stay in Florida longer. One can imagine how inconvenient would it be for a single mother of four to unpack and re-register all of her children back into school and to figure out her living situation after canceling her lease. This is hardly an example of effective communication.

\section{Discussion Questions}

1. Discuss some of the common mistakes made by managers at this organization. How could such mistakes be prevented?

2. What can employee do to better deal with managers who are dogmatic and abusive?

3. What can human resource managers do to make sure managers do not abuse their authority or violate the company's policies and procedures?

4. What can be done to better integrate some of the main principles of the effective management and communication practices into the merged company?

\section{CONCLUSION}

The takeover of Alveolar in Healthcare Incorporated's recent merger could have potentially resulted differently if perhaps it had not been for management constraints such as those mentioned in this case as well as non-compliance for suitable HR practices. The possibility exists that if Alveolar had been the stronger of the two implant companies, headquarters would not be moving out of state to the Horizons Dental location and many employees of Alveolar could still be employed under more sound management conditions. The only management 
technique that has been developed by Alveolar and applied across national boundaries is the advance biotechnology used to sell the dental implant product line, and this was the main focus upon training sales staff worldwide; however it seems to not have been enough. It is safe to say that management constraints and poor human resource practices on a firm's behalf can shape and predict not only the future of a company but can also have devastating effects on employee attitudes and behavior and realistic proof of this is this case.

\section{REFERENCES}

1. Cornell, Christopher (September 2006). 5 Blunders HR Professionals Should Avoid Making, and Too Often Don't. Retrieved from http://www.hreonline.com/HRE/story.jsp?storyId=6844134 on June 2, 2007.

2. Dowling \& Welch (2005). International Human Resource Management (pgs 45, 58-60, 67-75).

3. Marks, Richard Lee (November 2005). Do's and Don't's of Merger Management. Retrieved from http://www.asaecenter.org/PublicationsResources/ANowMagSidebarDetail.cfm?ItemNumber=14026 on June 7, 2007.

4. Massad, Mary (n.d.). HR pros on 'The Apprentice' -- don't try this in real workplace. HR Edge. Retrieved from http://www.bizjournals.com/solutions/hr11.html on June 2, 2007.

5. NAI, 1 (n.d.). Retrieved from http://www.Alveolar.com/index3c/index3c.mv?pg=aboutUs/about on May 16, 2007.

6. $\quad$ NAI, 2 (January 2006). Alveolar International Inc. Employee Handbook.

7. Robertson, Lori (September 2003). Down with Top-Down. American Journalism Review. Retrieved from http://www.ajr.org/Article.asp?id=3062 on May 21, 2007.

8. $\quad$ Schmalensee, R. (2006). Where's the 'B' in B-Schools? BusinessWeek; November 27, p. 118. 